\title{
Legal Transplant and the Model of Constitutional Court Decision
}

\author{
Bisariyadi* $^{*}$ \\ DOI: https://doi.org/10.22304/pjih.v5n1.a1
}

Submitted: August 23, 2017 | Accepted: April 13, 2018

\begin{abstract}
The Indonesian Constitutional Court may, at times, uses concepts and models of laws from other countries. The transplantation of foreign laws can be organic or mechanic. The model of legal transplantation in the procedural law is an organic transplantation. The transplants can be problematic since it requires a compliance with the legal system in the recipient system. This article focuses on the practices of legal transplant by the Indonesian Constitutional Court in its procedural laws, especially in regards to their decisions. It mainly concerns on (i) the formulation of constitutional injuries criteria to give standing for parties to access before the Court; and (ii) the adoption of conditional (un)constitutionality decisions. It also discuss the source from which the Court find the similar practices and to what extend the Court made some adjustments in order to suits in its procedural law. The article also argue that legal transplant in procedural law may found adversities. In order to overcome these, the Court needs to made alteration to the foreign laws.
\end{abstract}

Keywords: Constitutional Court, foreign laws, legal transplant.

\section{Pencangkokan Hukum Asing dalam Model Putusan Mahkamah Konstitusi}

\begin{abstract}
Abstrak
Mahkamah Konstitusi kerap mencangkok konsep dan model hukum yang berlaku di berbagai negara untuk diadopsi dalam putusan Mahkamah Konstitusi, baik dalam arti pencangkokan yang bersifat organis maupun mekanis. Pencangkokan hukum dalam hukum acara termasuk dalam sifatnya yang organis. Model transplantasi ini bisa memicu pada ketidaksesuaian dalam penerapannya pada hukum acara pada sistem hukum yang akan mengadopsinya. Tulisan ini menitikberatkan pada praktik Mahkamah Konstitusi yang mencangkok model hukum asing untuk diterapkan dalam hukum acara terutama dalam perumusan model putusannya. Yang menjadi perhatian dalam tulisan ini adalah mengenai (i) penentuan kriteria kerugian konstitusional dalam kedudukan hukum pemohon (legal standing); dan (ii) jenis putusan (in)konstitusional bersyarat (conditionally (un)constitutional). Tulisan ini akan menyigi sumber inspirasi Mahkamah Konstitusi menemukan model tersebut serta sejauh mana pengembangan yang dilakukan oleh Mahkamah Konstitusi. Tulisan ini bertujuan untuk membuktikan bahwa pencangkokan model hukum asing dalam hukum acara Mahkamah Konstitusi juga menemukan beberapa hambatan. Dalam rangka menghadapi hambatan tersebut, Mahkamah Konstitusi melakukan penyesuaian atas konsep hukum asing yang diadopsinya.
\end{abstract}

Kata kunci: hukum asing, Mahkamah Konstitusi, pencangkokan hukum.

PADJADJARAN Journal of Law Volume 5 Number 1 Year 2018 [ISSN 2460-1543] [e-ISSN 2442-9325]

Mahkamah Konstitusi Republik Indonesia (The Constitutional Court of the Republic of Indonesia), Jalan Medan Merdeka Barat No. 6 Jakarta Pusat, bisariyadi@mahkamahkonstitusi.go.id., S.H (Universitas Indonesia), LL.M (University of Melbourne). The author would like to thank Balai Bahasa Universitas Pendidikan Indonesia for assisting the translation of this article. Views, thoughts and opinion express in the text belong solely to the author. 


\section{A. Introduction}

Laws, including constitutional law, do not exist in an isolated space. ${ }^{1}$ The constitutional law derived its source within the society, from the practice of laws by the community in domestic or from other countries. Observation of laws from other countries may create relations. The relation is mutual. During the interaction, they may influence each other. And at certain point, there is strong possibility of a unification or as Mark Tushnet coined it as a "constitutional convergence". 2

The interaction process and the adoption of laws from other countries is the main focus of comparative study. Scholars introduce different terminologies that tend to have distant definition and they are not identical. The terms "transplant", "borrowing", "reception", "migration", ${ }^{6}$ are some of them which followed by academic debates over the uses of these terminologies. ${ }^{7}$ However, this essay will not go into further detail on the debate. It will use the term "legal transplant" as introduce by Alan Watson. ${ }^{8}$ Watson defines legal transplant as "moving a rule or a system of law from one country to another or from one person to another". ${ }^{9}$

The definition influences other scholars. Later, Otto Kahn-Freund interprets Watson's definition of legal transplant by providing example and typology. KahnFreund explained that legal transplant is similar to the conception of "transplant" in medical science and mechanical engineering. Medical science reckons the human organ transplantation. And in engineering, transplant is use to define a process of

\footnotetext{
Sujit Choudhry, "Globalization in Search of Justification: Toward a Theory of Comparative Constitutional Interpretation", Indiana Law Journal, Vol. 74, Issue 3, 1999, p. 821; Vicki C. Jackson, "Foreword - Comment: Constitutional Comparisons, Convergence, Resistance, Engagement", Harvard Law Review, Vol. 119, No. 1, 2005, p. 111; Anne-Marie Slaughter, "A Global Community of Courts", Harvard International Law Journal, Vol. 44, No. 1, 2003, p. 192; Mark Tushnet, "The Possibilities of Comparative Constitutional Law", Yale Law Journal, Vol. 108, No. 6, 1999, p. 1230.

2 Mark Tushnet, "The Inevitable Globalization of Constitutional Law", Virginia Journal of International Law, Vol. 50, No. 1, 2009, p. 987.

3 Edward M. Wise, "The Transplant of Legal Patterns", The American Journal of Comparative Law, Vol. 38, 1990, pp. 1-22.

4 Berry Friedman and Cheryl Saunders, "Introduction to the Symposium on Constitutional Borrowing", International Journal of Constitutional Law, Vol. 1, No. 2, 2003, pp. 177-180; Wiktor Osiatynski, "Paradoxes of Constitutional Borrowing", International Journal of Constitutional Law, Vol. 1, No. 2, 2003, pp. 244-268.

5 Wolfgang Wiegand, "Reception of American Law in Europe", American Journal of Comparative Law, Vol. 39, No. 2, 1991, pp. 229-248.

$6 \quad$ Sujit Choudhry, "Reception of American Law in Europe", American Journal of Comparative Law, Vol. 39, No. 2, 1991, pp. 229-248; “Migration as a New Metaphor in Comparative Constitutional Law" in Sujit Choudhry (ed.), The Migration of Constitutional Ideas, Cambridge: Cambridge University Press, 2006, pp. 1-37.

7 Gianmaria Ajani, "By Chance and Prestige: Legal Transplants in Russia and Eastern Europe", American Journal of Comparative Law, Vol. 43, No. 1, 1995, pp. 93-117; Vlad Perju, "Constitutional Transplants, Borrowing and Migrations", in M. Rosenfeld and A. Sajo (eds.), Oxford Handbook of Comparative Constitutional Law, Oxford: Oxford University Press, 2012, pp. 1304-1327.

8 Alan Watson, Legal Transplants: An Approach in Comparative Law, Georgia: University of Georgia Press, 1974, p. 21.

A lengthy discussion of Watson's idea on legal transplant has not far from critics. One and most contending of which is from Pierre Legrand. See Pierre Legrand, "The Impossibility of Legal Transplants", Maastricht Journal of European and Comparative Law, Vol. 4, Issue 2, 1997, pp. 111-124.

$9 \quad$ Alan Watson, Op.cit., p. 22.
} 
exchanging of engine components from one to another engine. Kahn-Freund calls the first "organic" and the latter as "mechanical". ${ }^{10} \mathrm{He}$ argues that the categorization shows the level of difficulty in its transplantation process. As similar to human organ transplantation in medical science, the organic legal transplant is never an easy process. The organic transplants in legal system strongly relates to the livelihood of the people, social systems, and values prevailing in the community. Constitutional issues, as Kahn-Freund acknowledge, include in organic legal transplant because the constitution provide a rule that concerns the distribution of power among state institutions and the constitution also impose the protection of citizen rights. ${ }^{11}$

The Indonesian Constitutional Court (Mahkamah Konstitusi), in its judicial decision-making process, is familiar with the use of comparative approaches. There is a study that was dedicated to examine the use of foreign laws as a reference in the Court decisions, where it found 813 references to the concept of foreign laws in 62 decisions. ${ }^{12}$ The figure indicates the Court open attitude to make references to foreign laws in their quest to solve constitutional cases. However, no study has yet touch on the issue of the reason behind the Court to use foreign laws as reference, as well as the benefits of making such reference.

In her research, however, Zhang does not distinguish between "foreign laws" and "international laws". In comparative study, both are distinctives. "Foreign laws" defines as a law that applies outside domestic jurisdiction. It may also be applied on the differences of legal tradition, either common law or civil law, or in legal system based on religious teachings, between Islamic law (Sharia) and Hindu laws. For example, a research on comparative law of corruption eradication practices in Indonesia and the Netherland. For Indonesian who conducted the research, Dutch law treated as foreign law since the law is observes from the Indonesian law perspective. It employs the same in relation to the comparison of legal system. The legal tradition adopted by the country of origin becomes the starting point for comparisons of foreign legal system. Indonesia that has rooted in civil law tradition will view common law as foreign law.

In terms of constitutional interpretation, a scholar has criticizes the use of foreign law. He concludes that foreign law cannot be used as a proposition to justify a constitutional court decision. The foreign law may only act as a persuasion to the audience but may not play the role as a source of legitimacy. ${ }^{13}$

"International law", on the other hand, defines as public international law. It refers to legal instruments issued by international organizations in the forms

10 Otto Kahn-Freund, "On Uses and Misuses of Comparative Law", The Modern Law Review, Vol. 37, Issue 1, 1974, pp. 5-6.

11 lbid., p. 7.

12 Diane Zhang, "The Use and Misuse of Foreign Materials by the Indonesian Constitutional Court: A Study of Constitutional Court Decisions 2003-2008" in Pan M. Faiz, "Legitimasi Rujukan Hukum Asing Dalam Putusan MK", Majalah Konstitusi, No. 83, January 2014, p. 62.

13 Ganesh Sitaraman, "The Use and Abuse of Foreign Law in Constitutional Interpretation", Harvard Journal of Law and Public Policy, Vol. 32, No. 2, 2009, p. 691. 
of conventions and protocols. In addition, the instruments also provide general principles of international law which have strong acceptance by countries. The principles may apply as references or a ground for judicial review in comparative studies as well as in constitutional interpretation. ${ }^{14}$

Legal transplant, as will be discussed here, is in a different form. The Constitutional Court uses foreign laws not only as references for judicial decision-making. The Court also transplanted foreign laws as part of its procedural laws. For example, in the admissibility test, the Constitutional Court Law ${ }^{15}$ imposes that the parties must explain their qualifications and their claims of constitutional injury. The law does not define the scope of "constitutional injury". Therefore, the Court formulates criteria of constitutional injury that must be met by the parties. In its formulation, the Court transplanted the constitutional injury criteria from other constitutional jurisdiction. Along with constitutional injury doctrine, the Court also adopted a type of holding which coined as "conditionally (un)constitutional". This holding was inspired by the practice from other constitutional jurisdiction. Even though the holding is regarded as part of their procedural law, as provided in the Law on Constitutional Court, it was not regulated in the Law.

Legal transplant is a common practice in the constitutional adjudication. The adoption of proportionality test is a good example. Proportionality test is a method to measure a different view on conflicting rights or when the court face between dilemma of deciding the protection of individual rights or for the sake of state interests. The test set up a priority, to determine what interests should be take the first consideration. Proportionality test facilitates judicial decision-making process as it provides an analytical structure for judges to give their deliberation. ${ }^{16}$ In historical perspective, proportionality tests have strong roots in German legal tradition. Prior to the development of constitutionalism, the administrative courts in Germany had already developed this method. The very first case on the the record is when the administrative court trial the policy on police authority in the case Polizeirecht. ${ }^{17}$ As the German Basic Law came into force in 1949, the proportionality test also applied in constitutional cases. ${ }^{18}$ The Basic Law stipulates provisions which regard as a catalog of citizens' rights. Thus, the breach of those rights is a constitutional case. First decision of the Constitutional Court that uses the proportionality analysis is the case on Drug Store in $1958 .{ }^{19}$ The Court is not a single actor who develops

14 Konrad Zweigert and Hein Kotz, Introduction to Comparative Law, (translation by Tony Weir), Oxford: Clarendon Press, 1998, pp. 7-8.

15 Law Number 8 of 2011 on the Amendment to Law Number 24 of 2003 on the Constitutional Court.

16 Mattias Kumm, "Constitutional Rights as Principles: On the Structure and Domain of Constitutional Justice", International Journal of Constitutional Law, Vol. 2, Issue 3, 2004, p. 579.

17 Alec Stone Sweet and Jud Mathews, "Proportionality Balancing and Global Constitutionalism", Columbia Journal of Transnational Law, Vol. 47, 2008, p. 98.

18 Ibid., p. 104.

19 Decision of the German Constitutional Court Number 7 Entscheidungen des Bundesverfassungsgerichts (BverfGE) 377, 1958 (Drug Store Case). Translation of decision into English in Donnald Kommers, The Constitutional Jurisprudence of the Federal Republic of Germany, Durham: Duke University Press, 1997, p. 532. 
the proportionality analysis. German scholars also have a major contribution in the improvement of proportionality test with their academic writings where the German Courts often cited their texts. ${ }^{20}$ From the German practice, the proportionality test began to have recognition and spread around Europe. It is adopted by constitutional courts in Central and Eastern European countries. ${ }^{21}$

On the other side of the world, a method similar to proportionality test has also developed in the United States. The United States Supreme Court (US Supreme Court) introduces "balancing doctrine". In its analytical structure, however, the balancing doctrine and proportionality test is not much of a different. ${ }^{22}$ The similarity between the two can be seen from the adoption of the structure of proportionality analysis as applied in the Supreme Court of Canada. In the case of $R$. v. Oakes, ${ }^{23}$ the Supreme Court of Canada interprets the limitation clause stipulated in the Canadian Charter of Rights and Freedom. In its reasoning, the Court introduced the basic framework of proportionality test, which then became popular as "the Oakes test". The test has some similarities to the ratio decidendi of the US Supreme Court in the case of Central Hudson Gas \& Electric Corp. V. Public Service Commission of New York. ${ }^{24}$ This suggests that the Oakes test may takes its inspiration from the balancing doctrine as developed by the US Supreme Court. Nevertheless, there is also the opinion that the Oakes test is adopted from the proportionality test from the German practice. ${ }^{25}$

The above example shows how a legal method can be adopted in other jurisdictions. It may also be modified to suit the domestic situation and with its legal framework. It also happen in the attempt to adopt constitutional injury doctrine and the holding of "conditionally (un)constitutional in the Indonesian Constitutional Court. Both are part of procedural law. In Kahn-Freund's taxonomy, procedural law belongs to the organic legal transplant. It suggests that the process of legal transplant is not a smooth task. It may even end in the abuse of comparative approach. KahnFreund cautioned, "...the attempt to use foreign models of judicial organization and procedure may lead to frustrations and may be a misuse of the comparative method." ${ }^{26}$ This article is based on the warning conveyed by Kahn-Freund. It discusses the difficulties faced in the legal transplant process of the use of constitutional injury doctrine and the Court's decision that hold conditionally (un)constitutional.

This article is divided into three parts: (i) introduction; (ii) discussion, which shall consist of two sub-sections on legal transplant in the formulation of the criteria for

\footnotetext{
Alec Stone Sweet and Jud Mathews, Op.cit., pp. 105-107.

Wojciech Sadurski, Rights Before Courts, A Study of Constitutional Courts in Postcommunist States of Central and Eastern Europe, Drodrecht: Springer, 2008, p. 287.

22 Moshe Cohen-Eliya and Iddo Porat, "American Balancing and German Proportionality: The Historical Origin", International Journal of Constitutional Law, Vol. 8, Issue 2, 2010, p. 270.

Decision of the Canadian Supreme Court, 1 S.C.R.103, 1986.

24 Decision of the United States Supreme Court, 447 U.S. 557, 1980.

25 Dieter Grimm, “Proportionality in Canada and German Constitutional Jurisprudence”, University of Toronto Law Journal, Vol. 57, 2007, p. 384.

26 Otto Kahn-Freund, Op.cit., p. 20.
} 
constitutional injury and legal transplant in the adaptation of a conditional (un) constitutional decision; and (iii) conclusion.

\section{B. Legal Transplant in the Formulation of Constitutional Injury Doctrine}

Article 51 of the Law Number 8 of 2011 on the Amendment to the Law Number 24 of 2003 on the Constitutional Court (Indonesian Constitutional Court Law) include as part in the chapter on the Court's procedural law. ${ }^{27}$ It regulates on parties that allowed with access to submit judicial review case. The article defines petitioner as a party who deemed their constitutional rights/powers has been infringed. Thus, it consists of two elements in the definition of petitioner, (i) parties and (ii) the injury of constitutional rights/powers. "Parties", as mentioned in article 51(1), include: (a) individuals; (b) indigenous community; (c) public/private legal entity; and (d) state institutions.

A question arises on what define as "constitutional rights/authorities injury"? The elucidation on article 51(1) of the Indonesian Constitutional Court Law elaborates that constitutional rights "is the rights mentioned in the 1945 Constitution". In addition, article 51(2) of the Law stipulates the obligation of the parties to describe and proof their injuries. Although, both the elucidation and Article 51(2) of the Law, has provide a definition of constitutional injuries but the extent to what constitutes as "constitutional injuries" still remain vague.

Two years after the establishment, the Court formulated the criteria for constitutional injuries. ${ }^{28}$ Later, the basic formulation has several revisions. The addition to the word "powers" on the first criteria to accommodate state institutions ${ }^{29}$ and the Court addition on en masse nature of the criteria are two of the revisions. The en masse or cumulative nature ${ }^{30}$ means that non-compliance to any single criteria will result in an "inadmissible" decision where the Court holds that the petitioner has no standing to file a judicial review case.

In its structures, the five criteria can be categorized into two groups, (i) elements and (ii) measures. The first two criteria are "elements" and the latter three are

27 Chapter V of the Law Number 24 of 2003 on the Constitutional Court (Indonesian Constitutional Court Law) imposes Procedural Law. Article 51 (section 8th) of the Law is a special arrangement concerning judicial review procedure.

28 The formulation of constitutional injuries criteria was introduced in Decision of the Constitutional Court Number 006/PUU-III/2005 on the Review of Law Number 32 of 2004 on Regional Government, where the Constitutional sets the criteria of injuries that must be met by the parties must include:

a. a constitutional right of the parties;

b. the right is infringed by the Law under review;

c. the injuries must be specific and actual or have the potential to be occur;

d. there is a causal relationship (causal verband) between the injuries and the Law;

e. there will be remedy if the case is granted by the Court.

29 The criteria, initially, emphasized only on the element of 'rights'. Then, the Constitutional Court added an element of 'power ' to accommodate 'state institutions' as parties in judicial review case. The word 'power' in the criteria firstly introduce in the Decision of the Constitutional Court Number 12/PUU-V/2007 on the Review of Law Number 1 of 1974 on Marriage.

30 Introduces for the first time in the Decision of the Constitutional Court Number 11/PUU-V/2007 on the Review of Law Number 56, Prp of 1960 on the Size of Agricultural Land. 
"measures". "Elements" means that the parties must describe and show (i) their rights/powers eare stipulated in the constitution and (ii) the injuries they suffered. The "measure" means that the above elements must meet the following tests: (i) the injuries must be specific and actual or at least have a strong possibility to happen; (ii) there is a causal relation between the injuries and the Law under reviewed; and (iii) there will be remedy or at least the rights will not be infringed if the Law was annulled.

A close examination reveals that the type of test in the measurement criteria of constitutional injuries has similarities with "standing doctrine" in the United States. The standing doctrine consists of injury-in-fact, cause of effect, and redressibility. The doctrine is formulated in the attempt of interpreting Article III of the US Constitution.

The similarity of standing doctrine with the criteria of constitutional injuries, especially in its measurement, is acknowledged by Justice Maruarar Siahaan. He was a member of the Court in the period when the Court introduces the criteria. However, Siahaan further explain that the doctrine is not entirely transplanted in determining injuries in the Indonesian context. ${ }^{31}$ The addition of "elements" in the criteria is a modification that differs it from standing doctrine. The legal transplant as conducted by the Court is not a blind copy-paste model. Rather, it is a "synchronization-harmonization" 32 that takes into account the needs and the context of the Indonesian Constitutional Court situation.

A study by Stefanus Hendrianto has come to a similar conclusion. The Indonesian Constitutional Court is doing a legal transplant, or Hendrianto prefers the idea of "constitutional borrowing", in formulating criteria of constitutional injuries. ${ }^{33}$ The terms "borrowing" means that it covers a one-way communication from "donor" state with the long history in applying the legal concept to a "recipient" facing a more or less similar problem for the very first time. ${ }^{34}$ This is not occurs in the process of applying standing doctrine in the Indonesian Constitutional Court. The difference is in the scope of consitutional adjudication. The Indonesian Constitutional Court applies the criteria to give access for parties to submit "abstract norm" review or a model of "quasi-public" rights. Whereas, cases in the US Supreme Court is related to a more concrete cases of the infringement of individual right. ${ }^{35}$ In addition, the application of the injury criteria has the potential to be governed by the political preference of the judges rather than by the doctrinal authority in judicial decisionmaking. ${ }^{36}$

31 Interview with Maruarar Siahaan (Justice at Constitutional Court in 2003-2008; 2008-2009).

32 María Paula Reyes Gaitán, "The Challenges of Legal Transplants In A Globalized Context: A Case Study On 'Working' Examples", a thesis for the Program of Master of Laws in the University of Warwick, 2014, pp. 12-13.

33 Stefanus Hendrianto, "Convergence or Borrowing: Standing in the Indonesia Constitutional Court", Constitutional Review, Vol. 1, No. 1, 2015, p. 46.

34 Rosalind Dixon and Eric Posner, "The Limits of Constitutional Convergence", Chicago Journal of International Law, Vol. 11, No. 2, 2011, p. 408.

35 Stefanus Hendrianto, Op.cit., p. 42.

$36 \quad$ Ibid., p. 46. 
It clearly identifies in the consideration to give standing for taxpayers. Arguably, the qualification of individual who claim themselves as taxpayer should have causal relation the Law under review - for example, in terms of submission of a case to review the Law on Tax Amnesty. ${ }^{37}$ Nonetheless, the Court have given standing for individuals who have proven themselves as taxpayers even though the law is not regulate on taxes or fiscal administration. ${ }^{38}$

The debate over giving access to the taxpayer has been around for a long time. During Jimly Asshiddiqie's Court, a taxpayer was first given a legal standing to review the Law on Government Bonds. ${ }^{39}$ Later, the access for taxpayer becomes more relaxed during Mahfud MD's Court. ${ }^{40}$

In its initial design, the constitutional injuries criteria are used in judicial review cases, both formal and material review. However, in the case on the review of the Law Number 3 of 2009 on Amendment to the Law Number 14 of 1985 on the Supreme Court (Indonesian Supreme Court Law), ${ }^{41}$ the Court replenishes the criteria for a formal review of the Law. The Court came to a conclusion that the nature of formal and material review of the Law are different so that the use of the same criteria for constitutional injuries in both cases means the failure to understand the distinctive nature of a formal review.

In the submission for a formal review, a criterion must be met where the parties have the burden to prove their direct causal linkage to the Law. ${ }^{42}$ The Court does not

37 Decision of the Constitutional Court Number 63/PUU-XIV/2016 on the Review of Law Number 11 of 2016 on Tax Amnesty, para. 3.5. (the Parties in the case, -Serikat Buruh Sejahtera Indonesia, Konfederasi Serikat Pekerja Indonesia, and Partai Buruh -, are 'legal entities' that claim themselves as taxpayers); Decision of the Constitutional Court Number 59/PUU-XIV/2016 on the Review of Law Number 11 of 2016 on Tax Amnesty, para. 3.5. (the parties are 'individual citizens', acted as taxpayers).

38 Decisions where the Court give standing for parties in the qualifications of taxpayers are:

1. Decision of the Constitutional Court Number 75/PUU-X/2012 on the Review of Law Number 32 of 2004 on Regional Government, para. 3.8 and para. 3.9;

2. Decision of the Constitutional Court Number $8 / P U U-X / 2012$ on the Review of Law Number 15 of 2011 on Electoral Commission, para. 3.8.1;

3. Decision of the Constitutional Court Number 49/PUU-IX/2011 on the Review of Law Number 8 of 2011 on Amendment to Law Number 24 of 2003 on the Constitutional Court, para. 3.8 and para. 3.9.

In the above decisions, the Court is silent on the form of injuries, the absence of causality relation and possible remedy. The Court saw that the petitioners have been able to show themselves as taxpayers who actively involved in supervision governmental policies. In addition to their status as law professors in universities.

39 Decision of the Constitutional Court Number 003/PUU-I/2003 on the Review of Law Number 24 of 2002 on Government Bonds, p. 49.

An important note that the decision was issued before the formulation of constitutional injuries criteria. Here, two constitutional judges submit their dissents (Justices names were undisclosed) on the grounds that the constitutional injuries must be specific and constitute an actual or potential injuries with a close relation to the law under review.

40 Decision of the Constitutional Court Number 5/PUU/IX/2011 on the Review of Law Number 30 of 2002 on the Commission for Eradication of Corruption, para. 3.10.

The Constitutional Court give standing to individual who have show themselves as tax payers and to have an interest in the eradication of corruption. Therefore, the individual have the standing to submit a review on the term of office of substitute chairmanship of Komisi Pemberantasan Korupsi as lay down in Law Number 30 of 2002 on the Commission for Eradication of Corruption.

41 Decision of the Constitutional Court Number 27/PUU-VII/2009 on the Formal Review of Law Number 3 of 2009 on Amendment to the Law Number 14 of 1985 on the Supreme Court.

$42 \quad$ Ibid., p. 68. 
provide any explanation to the meaning of "direct causal linkage". Thus, the Court still opens to any possibility. A strict application of "direct causal linkage" will only cause many parties to be inadmissible. It will be hard for the Court to protect the constitutional rights due to the narrow interpretation to the criteria. In the decision, some judges dissents and argues that a more specific criterion in determining standing in a formal review of the law is needed. ${ }^{43}$ Therefore, a more definitive criteria to the "direct causal linkage" must be applied for formal review.

In the review of the Indonesian Supreme Court Law, four parties submitted the case in their qualification as individual. The Court holds to give access for one party (Petitioner I) and rejects the standing of other. Petitioner I met the criteria of having "direct linkage" because of his occupation as advocate. The Court considered that in carrying out his profession, an advocate has a direct link with the Supreme Court which is the object of the review. ${ }^{44}$ Meanwhile, other parties who work as teacher, private business owner, and civil servant were considered not to have a direct linkage to the Supreme Court.

Direct linkage as applied in formal review cases is a specific form of causality in the constitutional injuries criteria. In a material review, the constitutional injuries criteria did not impose any specific form of causal relation. In practice, however, the measure of direct relation may still be very flexible. The advocate as petitioner to review the Law on Supreme Court may still be questioned on his relation to the Supreme Court. Does his constitutional right as an advocate directly infringed by the enacted Law?

Standing doctrine, as applied in the US Supreme Court, has another approach. The Indonesian Supreme Court (Makhamah Agung) does not put emphasize on the nature of the relationship, either directly or indirectly. Their main concern is whether the causal relationships that occur were measurable. It emphasizes on the phrase of "fairly trace(able)" as a measure in assessing the causal relationship between the

43 A number of dissent judges as well as concur, argue the need to further define the criteria of 'direct linkage'.

1. Justice Arsyad Sanusi (in his concurring opinion) proposed that the requirement of constitutional injuries that the parties must possess in a formal review is that if the petition is submitted by an individual. The party must prove the existence of a legal constitutional rights, whereas a submission by public legal entity or public official must prove the legal constitutional interest. Decision of the Constitutional Court Number 27/PUU-VII/2009 on the Formal Review of Law Number 3 of 2009 on Amendment to Law Number 14 of 1985 on the Supreme Court, pp. 109-111.

2. Justice Ahmad Sodiki (in his dissenting opinion) proposed criteria of constitutional injuries which must be met by the parties are (i) have the legal rights in drafting process of the bill; (ii) their interests are closely connected to the process of drafting the law; (iii) their interests are violated because the drafting process of the law formulation is not a due process, and (iv) the injuries can be prevented if the law-making process is in accordance to the due process. Decision of the Constitutional Court Number 27/ PUU-VII/2009, p. 128.

3. Justice Muhammad Alim (in his dissenting opinion) argued that the only party who may file a formal review are members of the House of Representatives and the President. Decision of the Constitutional Court Number 27/PUU-VII/2009 on the Formal Review of Law Number 3 of 2009 on Amendment to Law Number 14 of 1985 on the Supreme Court, p. 131. 
enactment of government policy and the injuries suffered by the parties. ${ }^{45}$

In addition, the nature of constitutional cases in the US is more of concrete cases that infringed the fundamental rights of individual. It is far different with the judicial review in Indonesia, which assesses the norms. In other words, the Court conducted an abstract review. Accordingly, the fulfillment of causal relation would mean that redressability of the injuries to the rights as required in standing doctrine is discernible.

Legal transplant of the standing doctrine to the constitutional injuries criteria as applied in the Indonesian constitutional adjudication is not a smooth process. The Indonesian Constitutional Court needs to make some adjustments and modifications to the criteria of constitutional injuries. However, it does not also mean that legal transplants have failed.

There is public acceptance to the constitutional injuries criteria. The criteria serves as an insight to the Indonesian Supreme Court to measure the infringement of legal rights in their judicial review cases. The constitutional mandate of the Indonesian Supreme Court is to review regulations in the hierarchy below the Law. ${ }^{46}$ This case may only be filed by parties who consider their legal rights to be infringed by the enactment of these types of regulations. ${ }^{47}$ Unlike the Indonesian Constitutional Court Law which stipulates the obligation of the petitioner to prove the infringement to their constitutional rights, the arrangement in the Supreme Court requires the violation to the statutory rights. Later, the Supreme Court formulates the criteria of infringement to the statutory rights which must be met by the parties. ${ }^{48}$ The Supreme Court is silent on how they have come to the formulation of the criteria. Especially, no words ever mentions that the criteria modeled after the Indonesian Constitutional Court's criteria of constitutional injuries. However, a close examination shows that the criteria in the Indonesian Constitutional Court and the Supreme Court have no fundamental difference other than the scope of rights regulated in each of the criteria.

\section{Legal Transplant in "Conditional (Un)constitutional"}

Other example of legal transplant in Indonesian Constitutional Court procedural law

Decision of the United States Supreme Court on Lujan v. Defenders of Wildlife, 504 U.S. 555, 560-561, 1992.

Article 24A(1) of the 1945 Constitution of the Republic of Indonesia.

47 Article 31A(2) Law Number 3 of 2009 on the Second Amendment of Law Number 14 of 1985 on the Supreme Court.

48 The Indonesian Supreme Court in Decision of the Constitutional Court Number 54 P/HUM 2013 issued on December 19, 2013 and Decision of the Constitutional Court Number 62 P/HUM/2013 issued on November 18, 2013 as well as other decisions as include Decision of the Constitutional Court Number 64 P/HUM/2013 and Decision of the Constitutional Court Number $11 \mathrm{P} / \mathrm{HUM} / 2014$ holds that the injuries of rights must meet 5 (five) requirements:

1. Rights as guaranteed in the legislation;

2. These rights are deemed to have been infringed by the enacted legislation and regulation;

3. The injuries are specific and actual or at least potential to have occur by logical reasoning;

4. There shall be causal relationships (causal verband) between the injuries and the enacted regulations;

5. There is a possibility that if the petitition was granted, the injury will not have happen. 
is in the decision model. The Indonesian Constitutional Court decision in judicial review, as regulated in the Indonesian Constitutional Court Law, consists of three forms. ${ }^{49} \mathrm{First}$, if the petition does not meet the requirements, on standing issue and not fall within the power of the Court, the petition is declare "inadmissible". Second, if the Court is of the opinion that the Law under review is in contradiction with the Constitution, the petition is declare "granted". Third, if the Law is not breached the Constitution, the Court must declare that the petition "rejected".

However, the Court introduces another form of decision which is not stipulated in the Law. The Court, in a number of decisions, holds to give the Law a condition of its constitutionality status. The Court coined the term "putusan konstitusional bersyarat". In some of the decisions, the Court provides an English term for this type of decision as "conditionally unconstitutional".

The idea to pair "putusan konstitusional bersyarat" with the English terms can be problematic. The phrase "conditionally unconstitutional" is not recognizes in English. Even more so, the words do not have any legal definition. In countries that use English as their native language the phrase of "conditionally unconstitutional" is not familiar or even available in legal dictionary. The idea to associate "putusan konstitusional bersyarat" with English words which do not have any reference to a legal concept may only mislead the audience.

Writing a judicial decision is an art in itself. It is different with legislative or contract drafting that have standard set of rules and structures. Judicial decision is a personal preference of the judge, ${ }^{50}$ even more so in judicial review case. Translation from foreign languages may have their own meaning. Audiences have the impression that a particular term that was used refers to a concept that has been generally accepted or at least practiced in other country. The adoption or citation of foreign languages in a legal practice has gradually been abandoned. However, in judiciary there is a tendency that "... judges often use phrases from dead or foreign languages. It is said that Latin is a dead language still alive in legal writing, including judicial opinions". ${ }^{51}$ Thus, the addition of English term "conditionally unconstitutional" is as a matter of fact is erroneous since the word does not provide any meaning due to its unavailability in legal concept, especially those using English as their native language.

The conditional constitutionality decision means that the Court holds the law under review is in accordance with the constitution as long as the law is read with the conditions sets up in the decision. The difference with the conditional unconstitutionality rulings is that the court, basically, in the opinion of strike down the law for its contradiction to the constitution. However, the law may still be in

49 Article 56(1) to (5) of the Law Number 8 of 2011 on the Amendment to the Law Number 24 of 2003 on the Constitutional Court.

50 Richard A. Posner, "Judges' Writing Styles (And Do They Matter)?”, The University of Chicago Law Review, Vol. 62, 1995, p. 1420.

51 Gerald Lebovits, Alifya V. Curtin, and Lisa Solomon, "Ethical Judicial Opinion Writing", The Georgetown Journal of Legal Ethics, Vol. 21, 2008, p. 259. 
force if the law is read in accordance with the requirements formulated by the Court. Both, initially have the same idea. In this decision, the Court sets conditions or inserts a new law in order for the Law to conform to the Constitution.

The conditional unconstitutionality decision is an evolution of conditional constitutionality. The Court has observed that in the experiences of the issuance conditional constitutionality decision the lawmaker was not pay attention to obey the court decision. Thus, the decision become ineffective. ${ }^{52}$ Changing the tone of the decision by stating that the law is contradictory to the constitution will force the Government and the House of Representatives to put more attention to the court decision. The reason behind this change is to push the government and the parliament to comply with the court decision. Nonetheless, the court still not put behind the condition constitutionality decision. There are few decisions where the court issue such decision even after the changes..$^{53}$ The explanation to the court decision is unfounded.

Another question was also linger. Where did the court find the insight to issue such type of holding? The Court decision provides no answer to the question. No court decisions have discusses the issue especially mentioning that the concept was a transplant from other countries. Literary texts written by constitutional judges are also silent on the issue.

The objectives to establish the Indonesian Constitutional Court may provide a clue to trace the source of insight of the conditional (un)constitutionality decision. The idea to establish constitutional courts is to protect the constitutional rights of citizens. In order to achieve it, constitutional courts must be designed to have a strong political standing in order to be able to review the enactment of a policy. As the power of the court growth and the political position of constitutional court strengthen to protect constitutional rights, it encourages the shift of the Constitutional Court's role from negative to "positive legislator". ${ }^{54}$ This conceptual as well as historical justification advance constitutional courts in some countries to reconstruct the law and not just to annul the Law. By reconstruct means that constitutional court inserts or adds a new rule to the Law, which is more or less as to practice the power of lawmaking by the parliament. Thus, it is said that the Court acted as "positive legislator". In their observation, Shapiro and Stone-Sweet provide that "... powerful constitutional courts often offers direct and specific instruction on how an unconstitutional statute can be re-drafted into constitutionality". ${ }^{55}$

In other constitutional jurisdictions, there are practices similar to the Indonesian

\footnotetext{
Decision of the Constitutional Court Number 54/PUU-VI/2008 on the Review of Law Number 39 of 2007 on Amendment to Law Number 11 of 1995 on Customs, para. 3.22.

53 Faiz Rahman and Dian Agung Wicaksono, "Eksistensi dan Karakteristik Putusan Bersyarat Mahkamah Konstitusi", Jurnal Konstitusi, Vol. 13, No. 2, 2016, p. 357.

54 Alec Stone Sweet, "The Politics of Constitutional Review in France and Europe," International Journal of Constitutional Law, Vol. 5, No. 1, 2007, p. 84.

55 Martin Shapiro and Alec Stone Sweet, "The New Constitutional Politic of Europe", Comparative Political Study, Vol. 26, No. 4, 1994, p. 404.
} 
Court's conditional constitutionality decisions. The German Constitutional Court (Bundesverfassungsgerichts), for instance, in their decision on the case to review the constitutionality on the abortion policy (1975). The decision of the German Court sets up a condition and an order to the parliament. The Court holds that if the decision is unenforceable then the parliament may apply criminal sanction in order to protect the fetal development in the womb. The Court stated that the unborn fetus also have the right to live. ${ }^{56}$ The background of the case is that, in 1974 , the German government issued Criminal Code. Article 218a of the Code stipulates that abortion, with the mother consent, is legal if it is conducted during the first 12 weeks of pregnancy. ${ }^{57}$ The policy is based on a study on the "periodic model" - in which this approach justifies that a pregnant woman may have to have an abortion within the first three months of pregnancy with another condition that the medical treatment must first be consulted with a medical professional. On the one hand, this approach heavily focuses on the right of the women. The German Constitutional Court is of the opinion that this provision is unconstitutional for several reasons. First, the court argues that the fetus in the mother's womb have to be consider as a natural person who is alive. Therefore, the fetus should have been regarded as a legal entity and have the constitutional rights that need to be protected, as includes the right to life, regardless of the period of pregnancy whether the first three month or the first semester. Second, the Court also took a consideration that the right to live of a fetus must be protected by the state, including the potential harm that may cause even by the mother. In order to implement the conditions as provided by the Court, the Parliament must apply different types of sanctions other than criminal. In special circumstances, a criminal approach can be imposed to protect the right to live of a growing fetus. The Court also took notice that if the development of the fetus is harmful to the mother's life, or at least may result in suffering for a pregnant mother's life, the abortion may be conducted and the action is exempted from criminal sanctions. ${ }^{58}$

Apart from the German practice, the Italian Constitutional Court also provides another example. The Italian Court issued two types of decision similar to a conditionally constitutional decision. The first type of the decision is when the Court inserted new rules on the Law (sentenze monito). Second type is when the Court issued a decision that sets up condition for the Parliament to take as reference in drafting a new Law (additive in principio)..$^{59}$ The Constitutional Court of Brazil

56 The Decision of the German Constitutional Court: 30 Entscheidungen des Bundesverfassungsgerichts [BverfDE], Federal Constitutional Court, 1 (1975), as translated in Vicki C. Jackson and Mark Tushnet, Comparative Constitutional Law, New York: Foundation Press, 2006, p. 112.

57 Article 218a of the German Criminal Code in the version of the Fifth Statute to Reform the Criminal Code, dated June 18, 1974.

58 Vicki C. Jackson and Mark Tushnet, Op.cit., p. 113.

59 Simone Penasa, "Constitutional Innovations Beyond Reforms: Legislative Enactment And Judicial Implementation Of The Constitution" in Giuseppe Bellantuono dan Federico Puppo (eds.), Convergences And Divergences Between The Italian And The Brazilian Legal Systems, Trento: Università degli Studi di Trento, 2015, p. 47; for comparison, see Giancarlo Rolla and Tania Groppi, "Between Politics and the Law: The Development 
(Supremo Tribunal Federal) also implies a similar form of decision which scholars coined as "manipulative judgment". ${ }^{60}$ In 2008, the Constitutional Court of Brazil introduces a decision that inserted a rule on a piece of legislation on constitutional complaints (Mandado de Injuncao) case Number 107. The highlight of the case is on the absence of rules for civil servant to have a strike. The Constitution of Brazil consists of specific rights for employee. The catalog of rights includes rights to strike. The constitution stipulated that a specific rule of civil servants right to have a strike must be regulated in the Law. After 20 years of the enactment of constitutional rule, no legislation was issued by the government to regulate protest by civil servants. Later, the absence of the Law on civil servants to go for a strike creates problem. In 2007, there is a mass movement by civil servants to stop working. This caused administrative turmoil in the government, especially in a national agency for social security which responsible to administrate pensions money. The protest lasted for several months caused thousands of retired employees not to receive their pension payments. The situation endorses the Court decision. The Court come to a conclusion to associate civil servants as labor. Thus, the Law on Labors were imposed for public servants temporarily until the government issued the special law governing the civil servants. The court argues that the issuance of the decision is to fill the legal gap. In their reasoning, the Court make a reference to the practices of inserting new rules in legislation as applied in the Italian Constitutional Court. ${ }^{61}$

In addition, similar types of decision are commonly found in constitutional adjudication in Central and Eastern European countries such as Hungary, Poland, and Slovenia. ${ }^{62}$ Hungary is an interesting model, especially in its early years of the 1990s. The Hungarian Constitutional Court has taken powerful steps by exceeding its constitutional roles. The Court was famous for its judicial activism approach. Much was influenced by their first Chief Justice, Laszlo Solyom. His influence was enormous in determining the direction on the Court policies. He considered himself as the founding father of Hungarian Constitutional Court. ${ }^{63}$ Many of the Government's strategic policies were abolished by the Court on the ground to protect the basic rights of citizens. For example, the government's privatization plan is canceled by the Constitutional Court since it is in contrary to the principle of equality ${ }^{64}$ Similarly, the welfare reforms proposed by the parliamentary coalition of Socialists and Free Democrats were subsequently revoked because they were not in accordance with

of Constitutional Review in Italy", in Wojciech Sadurski (ed), Constitutional Justice, East and West: Democratic Legitimacy and Constitutional Courts in Post-Communist Europe in a Comparative Perspective, The HagueLondon-New York: Kluwer Law International, 2003, pp. 151-153.

60 Leo Brust, "The Interpretation According to the Constitution and the Manipulative Judgments", Revista Direito GV Sao Paolo, Vol. 5, No. 2, 2009, pp. 136-152.

61 Thomas Bustamante and Evanila Godoi Bustamante, "Constitutional Courts as Negative Legislators: The Brazilian Case", in Allan Brewer-Carías (ed.), Constitutional Courts as Positive Legislators. Cambridge: Cambridge University Press, 2011, p. 303.

62 Wojciech Sadurski, Rights Before Courts, Op.cit., pp. 87-104.

63 Endre Babus, "The Superego of the Transformation. The First Eight Years of the Constitutional Court", The Hungarian Quarterly, Vol. 40, No. 153, 1999, p. 3.

64 Decision of the Constitutional Court Number 21/1990. 
the constitutional rights of citizens and violated the principle of legal certainty. ${ }^{65}$ Solyom argues the Court's action during his chairmanship was something that was needed. At that time, Hungary was in a democratic transition. The constitutional provisions only provide general principles. Hence, the interpretation to the constitutional provisions was necessary to avoid legal gap between the constitution provisions and the laws. Solyom states, "... the patchwork constitutions with their inconsistencies and gaps allowed these courts certain room for maneuvers and for developing the constitutional principles, substitute rules and creative interpretations". ${ }^{66}$ Furthermore, Solyom concludes that there is indeed a shift in the role of the Constitutional Court from "negative legislator" to "judicial legislation". ${ }^{67}$

The South Korean Constitutional Court has also applied a similar decision to the conditional unconstitutionality decision by making reference to the German Constitutional Court. ${ }^{68} \mathrm{~A}$ type of the German Court decision that adopted by the South Korea Constitutional Court is a decision where the Court sets up a condition to the Law under review. In the German language, the term that was used for this type of decision is "Verfassungskonforme Auslegung von Gesetzen". ${ }^{69}$ In the review of the Law on National Security, ${ }^{70}$ the South Korea Constitutional Court is of the opinion that there were several rules in the Law regarding its enforcement that ambiguous and may be use in the interest of the government. The law provides legal ground for the government to arrest and to imprison activists who fight for Korean unification, during the 1980s. In time of the review on the National Security Law by the South Korean Constitution Court, the political situation and the national policy over the issue have changed. The government introduce a policy that make an effort to have reconciliation with socialist regimes, both in North Korea and China. The Court is of the opinion that the Law is still needed to maintain national security and the annulment of the law will only creates political uncertainty in domestic situation. ${ }^{71}$ Therefore, the Law on National Security Act is constitutional but some provisions that ambiguous must be read in accordance with the condition as provided in the decision. ${ }^{72}$

65 Decision Number 43/1995 (VI. 30.) as cited in János Kis, Constitutional Democracy, Budapest, New York: Central European University Press, 2003, pp. 285-295.

66 Laslo Solyom, "The Role of Constitutional Court in the Transition to Democracy, with Special Reference to Hungary", International Sociology, Vol. 18, No. 1, 2003, p. 148.

67 Ibid.

68 Jibong Lim, "Korean Constitutional Court Standing at the Crossroads: Focusing on Real Cases and Variational Types of Decisions", Loyola of Los Angeles International and Comparative Law Review, Vol. 24, Issue 3, 2002, pp. 335-336; Jongcheol Kim, "Some Problems with the Korean Constitutional Adjudication System", Journal of Korean Law, Vol. 1, No. 2, 2001, pp. 34-36.

69 James M. West and Dae-Kyu Yoon, "The Constitutional Court of the Republic of Korea: Transforming the Jurisprudence of the Vortex?", The American Journal of Comparative Law, Vol. 40, Issue 1, January 1992, p. 99. Law Number 3318 on the National Security Act of South Korea.

71 Diane Kraft, "South Korea's National Security Law: A Tool of Oppression in an Insecure World", Wisconsin International Law Journal, Vol. 24 No. 2, 2006, p. 637.

72 Decision Number 89-Honka-113 issued on 2 April 1990, as cited in James M. West and Dae-Kyu Yoon, Op.cit., pp. 106-107. 
In a study based on comparative approach, Allan Brewer-Carias argues that a legal gap where the Parliament is absence to anticipate the development of society in the legislation, has led constitutional courts taking the initiative to create the law derived from basic principles of constitution. ${ }^{73}$ Thus, constitutional court acts as a positive legislator to replace the parliamentary responsibility to draft legislation until the lawmakers issue a new piece of legislation. Brewer-Carias categorizes constitutional justice as a positive legislator in 4 (four) roles, (1) create or insert provisions to the Constitutional provision; (2) replace parliamentary role by drafting new rules, altering the law, or postpone the enactment of law; (3) filling legal gap; and (4) replace parliamentary role in the review of legislations and regulations. ${ }^{74}$

The Indonesian Constitutional Court is silent on the source of their insight to adopt the conditional unconstitutionality decision. Nonetheless, the trace of the legal transplant to its adoption is visible. The migration of legal practices on the similar type of decision as applied in other constitutional adjudication is a characteristic of legal transplant. The idea, then, arrived and applied in the Indonesian Constitutional Court as part of their procedural law. It is important to note that the adoption of this legal idea is not a blind copy-paste model. Some adjustments were made in the transplant process.

In the Indonesian practice, the Court applied a different kind of model. Although, the Court sets up a condition but the holding of the court do not mention it as conditional constitutionality decision. This type of models applied on a stand-alone basis. It may be coined as a typical decision. ${ }^{75}$ There are two types of decisions in this group: (i) the Court defers the enforcement of the decision and (ii) the Court argues that a certain article is the core of the law under review.

The example of judicial deferral in the Indonesian Constitutional Court is when the court examines the constitutionality of the Law on Water Resources. The court holds that the law is in accordance with the constitution as long as the government applied the conditions as sets by the court in its derivative regulation. Thus, the decision on the constitutionality of the Law on Water Resources is pending until the government issues the regulation. If the government regulation is in contrary to the court's condition, then the Law shall be examined by the court for the second time. ${ }^{76}$ In other decisions, the court decided to postpone the enforcement of decision on the establishment of special court for corruption cases. The court provides a time frame of three years since the issuance of the decision to give the lawmakers the

73 Allan Brewer-Carías, "Constitutional Court as Positive Legislators in Comparative Law", this paper is presented for the General report before the XVIII International Congress of Comparative Law in International Academy of Comparative Law, George Washington University Law School, on July 27, 2010, p. 3.

74 Ibid.

75 Bisariyadi, "Atypical Rulings of the Indonesian Constitusional Court", Hasanuddin Law Review, Vol. 2, Issue 2, 2016, p. 227. In this study the number of atypical rulings in judicial review cases between 2003-2015 is 108 decisions. In comparison to the study of Faiz Rahman and Dian Wicaksono, Loc.cit., which focus on conditionally constitutional decisions in the same period (2003-2015) amounting to 103 decisions.

76 Decision of the Constitutional Court Number 058-059-060-063/PUU-II/2004 and 008/PUU-III/2005 on the Review of Law Number 7 of 2004 on Water Resources, p. 495. 
opportunity to made alteration on the Law on the Corruption Eradication Commission and the drafting of a new law to establish a special court on corruption. ${ }^{77}$ Another example is on the decision of simultaneous election for members of parliament and the president. The court issued the decision in early 2014, a few months before the 2014 election. But, after careful consideration the court argues that it is impossible to hold simultaneous election in 2014 election where important preparatory steps have been taken. The court decided that the decision will be enforced for the 2019 election. ${ }^{78}$

In other constitutional jurisdiction, the deviation to the final and binding nature of the decision is, in fact, a common practice. In Europe, for instance, the issue has been raised in the Conference of European Constitutional Courts (CECC) Congress where most of the reports of member states acknowledge that they have the experiences of adopting judicial deferral as a form of tactical balancing. ${ }^{79}$ In comparison to the reports, there is also a study dedicated to discuss the decisions of the Constitutional Court in European countries, namely Italy, Germany, Austria, and Romania that postpone the enforcement of their decision. ${ }^{80}$ The South Korean Constitutional Court also provide example of their experience in pending the enforcement of the Court decision. ${ }^{81}$

Pending the enforceability of the decision is a strategy undertaken by a constitutional court to avoid a pragmatic political conflict with other state institutions as well as to gain public supports. The increasing political and moral supports from public will make constitutional court able to gain public trust and give legitimacy to their decisions in the future. This is a conclusion of Dixon and Issacharoff research after analyzing some constitutional courts' decisions that have the experience to use judicial deferral as their political strategy. ${ }^{82}$

In conjunction with judicial deferral, the court also issued a modified form of judgment in which an article of the law considered as "the core" of the law. The annulment of the article would affect the law ineffective. Within this framework, several examples of the Constitutional Court's decisions to annul the whole law because the court decide the core article of the law in incontradiction with the constitution include in the decision of review of Law Number 20 of 2002 on Electricity, ${ }^{83}$ Law Number 9 of 2009 on Educational Board, ${ }^{84}$ Law Number 17 of 2012

Decision of the Constitutional Court Number 012-016-019/PUU-IV/2006, p. 289.

78 Decision of the Constitutional Court Number 14/PUU-XI/2013, para. 3.20.

79 Congress XV of the Conference of European Constitutional Courts (CECC) held in Bucharest, on 23-25 of May 2011 with the topic "Constitutional Justice: Functions and Relationship With The Other Public Authorities".

80 Valentina Bărbăţeanu, "The Action In Time Of The Constitutional Courts' Decisions", CKS Proceedings, Vol. 3, 2013, pp. 500-511.

81 Jonghyun Park, "The Judicialization of Politics in Korea", Asian Pacific Law and Policy Journal, Vol. 10, No. 1, 2008, pp. 107-108.

82 Rosalind Dixon and Samuel Issacharoff, "Living to Fight Another Day: Judicial Deferral in Defense of Democracy", Wisconsin Law Review, Vol. 4, 2016, p. 716.

83 Decision of the Constitutional Court Number 001-021-022/PUU-I/2003 on the Review of Law Number 20 of 2002 on Electricity.

84 Decision of the Constitutional Court Number 11-14-21-126-136/PUU-XI/2013 on the Review of Law Number 20 of 2003 on the National Education System and Law Number 9 of 2009 on Educational Legal Entity. 
on Cooperative, ${ }^{85}$ and Law Number 7 of 2004 on Water Resources. ${ }^{86}$

Legal transplant, especially in terms of procedural law, is never been a straightforward process. The obstacles are not on technicality but more on political consideration. The adjustment to the Constitutional Court decision model concerns the power of the judiciary as an independent institutions and its political relation with other state institutions. As experiences shows, the parliament is acted in conflict with the court. The parliament in the position that the court has exceeded its constitutional mandate by exercising a role that should be the responsibility of the parliament. In a number of times, there were political struggle between the Constitutional Court and the Parliament.

In Indonesia, there is the experience that the House of Representatives made an effort to constraint the power of the court by making an amendment to the Indonesian Constitutional Court Law. The parliament attempts to limit the decisions of the Indonesian Constitutional Court that made an alteration to the Law, which often cited as "ultra petita". The term itself is adopted from civil cases in which the court's decision may provide a dictum that is not in the request of the parties. The lawmakers argue that the power of the court must be restraint. Therefore, the amendment to the Indonesian Constitutional Court Law provide a strict rule on the types of decisions that the court should not be issued. ${ }^{87}$ However, the amendment to the law was review by the court. ${ }^{88}$ In its reasoning, the court provides examples of other constitutional adjudication that practice "ultra petita" as it refers to the South Korean Constitutional Court. The Law on Constitutional Court in South Korea gives a justification for the Court to use "ultra petita". ${ }^{99}$ The Court implied that "ultra

85 Decision of the Constitutional Court Number 28/PUU-XI/2013 on the Review of Law Number 17 of 2012 on Cooperation.

86 Decision of the Constitutional Court Number 85/PUU-XI/2013 on the Review of Law Number 7 of 2004 on Water Resources.

87 Articles 45A and 57(2a) Law Number 8 of 2011 on the Amendment to Law Number 24 of 2003 on the Constitutional Court:

Article 45A

"Putusan Mahkamah Konstitusi tidak boleh memuat amar putusan yang tidak diminta oleh pemohon atau melebihi Permohonan pemohon, kecuali terhadap hal tertentu yang terkait dengan pokok Permohonan."

[The decision of the Constitutional Court may not contain the rulings that the petitioner does not request or exceed the petition, except on certain matters related to the subject of the petition] Article 57(2a)

"Putusan Mahkamah Konstitusi tidak memuat: a. amar selain sebagaimana dimaksud pada ayat

(1) dan ayat (2); b. perintah kepada pembuat undang-undang; dan c. rumusan norma sebagai pengganti norma dari undang-undang yang dinyatakan bertentangan dengan Undang-Undang Dasar Negara Republik Indonesia Tahun 1945."

[The decision of the Constitutional Court does not consists of: a. rulings other than as intended in para (1) and (2); b. orders to lawmakers; and c. inserting a new norms in exchange of previous norms that are in contradiction to the 1945 Constitution]

Decision of the Constitutional Court Number 49/PUU-IX/2011 on the Review of Law Number 8 of 2011 on the Amendment to Law Number 24 of 2003 on the Constitutional Court.

89 Article 45 of the South Korean Law on Constitutional Court (1987),"The Constitutional Court shall decide only whether or not the requested statute or any provision of the statute is unconstitutional: Provided, that if it is 
petita" is a transplant from the South Korean practices. The Court used comparative approach to its reasoning to give weight and legitimacy that "ultra petita" is also practiced in other countries.

A similar parliamentary resistance, as it happened in Indonesia, also took place in Hungary. In their early years of establishment, the Hungarian Constitutional Court was a dominant actor in determining the direction of the country to be a democratic society..$^{90}$ It creates a political contest with the parliament who, mostly, against the court's decisions.

Otto Kahn-Freund's opinion is an important note to recall. He argues that transplant in law on procedure do not always end in success. Adjustment to the concept is needed to suit the condition of the "receiver". In addition, political consideration must also be a concerned to reduce conflicts with other state institutions, especially with the government and the parliament. For Constitutional Court, political strategy plays an important role to ensure that the courts maintain its independence and thus, provide legitimacy for their decisions. Constitutional adjudication is always intertwined with the intervention to the government's policies. It will reveal the power of a strong judiciary as well as a strong leadership within the Court. The politics inside the parliament added fuels to the political intrigues. ${ }^{91}$ Yet, one thing will remain eminent is the respect over constitutionalism.

\section{Conclusion}

The Indonesian Constitutional Court transplants foreign laws to their procedural law. The article discussed two examples of the legal transplant in the procedural law, the constitutional injuries criteria and the model of conditional constitutionality decisions. The Court is silent on the sources of insight for both examples. Nonetheless, this article shows that the similarities with foreign practice in the constitutional adjudication provide a trace that the Court adopting them from foreign laws. The constitutional injuries criteria have a similarity with the standing doctrine as formulated by the US Supreme Court. Additionally, the type of conditional constitutionality decisions may also be found in European countries, South American and also South Korea who have adopted it long before the establishment of the Indonesian Constitutional Court.

Legal transplant from foreign laws has never been an easy process. The process is not a copy-paste technique. There are some adjustments need to be takes. It

deemed that the whole provisions of the statute are unable to enforce due to a decision of unconstitutionality of the requested provision, a decision of unconstitutionality may be made on the whole statute" as cited in the Decision of the Constitutional Court Number 48/PUU-IX/2011 on the Review of Law Number 24 of 2003 on the Constitutional Court and the Review of Law Number 35 of 2009 on Drugs, para. 3.13.

90 Oliver W. Lembcke and Christian Boulanger, "Between Revolution and Constitution: The Roles of the Hungarian Constitutional Court" in Gabor Attila Toth (ed.), Consitution for a Disunited Nation: On Hungary's 2011 Fundamental Law, New York: Central European University, 2012, p. 277.

91 Nathan J. Brown and Julian G Waller, "Constitutional Courts and Political Uncertainty: Constitutional Ruptures and the Rule of the Judges", International Journal of Constitutional Law, Vol. 14, Issue 4, 2016, p. 836. 
needs some alterations tailored to the conditions of the recipients. This is also found in the legal transplant of procedural law in the Indonesian Constitutional Court. Adjustments are required to curtail some issues.

The Court needs to take a closer look on few adjustments that has been taken on the legal transplant. The adjustments brought up a wide variety of models which trigger some criticism to the judicial consistency of the court's decisions. A legal doctrine is developed based on consistency, not just a sound legal reasoning. If the Constitutional Court often makes some adjustment to the decisions and the spectrum of variety become diverse, the question of consistency will arise.

In summary, the Indonesian Constitutional Court's open attitude towards legal transplants from foreign laws should be appreciated. The Court opens a room for dialogue among the various jurisdiction of constitutional adjudication. As it is cited at the introduction, the law in reality, cannot live in isolation.

\section{References}

\section{Books}

Brewer-Carías, Allan (ed.), Constitutional Courts as Positive Legislators, Cambridge University Press, Cambridge, 2011.

Choudhry, Sunjit (ed.), The Migration of Constitutional Ideas, Cambridge University Press, Cambridge, 2006.

Jackson, Vicki C. and Mark Tushnet, Comparative Constitutional Law, Foundation Press, New York, 2006.

Kis, János, Constitutional Democracy, Central European University Press, New York, 2003.

Kommers, Donnald, The Constitutional Jurisprudence of the Federal Republic of Germany, Duke University Press, Durham, 1997.

Toth, Gabor Atilla (ed.), Consitution for a Disunited Nation: On Hungary's 2011 Fundamental Law, Central European University, New York, 2012.

Bellantuono, Giuseppe and Federico Puppo (eds.), Convergences And Divergences Between The Italian And The Brazilian Legal Systems, Università degli Studi di Trento, Trento, 2015.

Rosenfeld, M. and A. Sajo (eds.), Oxford Handbook of Comparative Constitutional Law, Oxford University Press, Oxford, 2012.

Sadurski, Wojciech (ed.), Constitutional Justice, East and West: Democratic Legitimacy and Constitutional Courts in Post-Communist Europe in a Comparative Perspective, Kluwer Law International, The Hague-London-New York, 2003.

Sadurski, Wojciech, Rights Before Courts, A Study of Constitutional Courts in Postcommunist States of Central and eastern Europe, Springer, Dordrecht, 2008. Watson, Alan, Legal Transplants: An Approach in Comparative Law, University of Gerogia Press, Georgia, 1974.

Zweigert, Konrad and Hein Kotz, Introduction to Comparative Law, (translation by Tony Weir), Clarendon Press, Oxford, 1998. 


\section{Other Documents}

Ajani, Gianmaria, "By Chance and Prestige: Legal Transplants in Russia and Eastern Europe", American Journal of Comparative Law, Vol. 43, No. 1, 1995. Kraft, Diane, "South Korea's National Security Law: A Tool of Oppression in an Insecure World", Wisconsin International Law Journal, Vol. 24, No. 2, 2006.

Kumm, Mattias, "Constitutional Rights as Principles: On the Structure and Domain of Constitutional Justice", International Journal of Constitutional Law, Vol. 2, Issue 3, 2004.

Lebovits, Gerald, Alifya V. Curtin, and Lisa Solomon, "Ethical Judicial Opinion Writing", The Georgetown Journal of Legal Ethics, Vol. 21, 2008.

Legrand, Pierre, "The Impossibility of Legal Transplants", Maastricht Journal of European and Comparative Law, Vol. 4, 1997.

Lim, Jibong, "Korean Constitutional Court Standing at the Crossroads: Focusing on Real Cases and Variational Types of Decisions", Loyola of Los Angeles International and Comparative Law Review, Vol. 24, Issue 3, 2002.

Osiatynski, Wiktor, "Paradoxes of Constitutional Borrowing", International Journal of Constitutional Law, Vol. 1, No.2, 2003.

Park, Jonghyun, "The Judicialization of Politics in Korea", Asian Pacific Law and Policy Journal, Vol. 10, No. 1, 2008.

Posner, Richard A., "Judges' Writing Styles (And Do They Matter)?", The University of Chicago Law Review, Vol. 62, 1995.

Gaitán, María Paula Reyes, "The Challenges of Legal Transplants In A Globalized Context: A Case Study On 'Working' Examples", Thesis for Master of Laws Program at the University of Warwick, 2014.

Shapiro, Martin and Alec Stone-Sweet, "The New Constitutional Politic of Europe". Comparative Political Study, Vol. 26, No. 4, 1994.

Sitaraman, Ganesh, "The Use and Abuse of Foreign Law in Constitutional Interpretation", Harvard Journal of Law and Public Policy, Vol. 32, No. 2, 2009.

Slaughter, Anne-Marie, "A Global Community of Courts", Harvard International Law Journal, Vol. 44, No. 1, 2003.

Solyom, Laslo, "The Role of Constitutional Court in the Transition to Democracy, with Special Reference to Hungary", International Sociology, Vol. 18, No. 1, 2003.

Stefanus Hendrianto, "Convergence or Borrowing: Standing in the Indonesia Constitutional Court", Constitutional Review, Vol. 1, No. 1, 2015.

Sweet, Alec Stone and Jud Mathews, "Proportionality Balancing and Global Constitutionalism, Columbia Journal of Transnational Law, Vol. 47, 2008.

Sweet, Alec Stone, "The Politics of Constitutional Review in France and Europe," International Journal of Constitutional Law. Vol. 5, No. 1, 2007.

Tushnet, Mark, "The Possibilities of Comparative Constitutional Law", Yale Law Journal, Vol. 108, No. 6, 1999.

,"The Inevitable Globalization of Constitutional Law", Virginia Journal 
of International Law, Vol. 50, No. 1, 2009.

West, James M. and Dae-Kyu Yoon, The Constitutional Court of the Republic of Korea: Transforming the Jurisprudence of the Vortex?, American Journal of Comparative Law, Vol. 40, Issue 1, January 1992.

Wiegand, Wolfgang, "Reception of American Law in Europe", American Journal of Comparative Law, Vol. 39, No.2, 1991.

Wise, Edward M., "The Transplant of Legal Patterns", American Journal of Comparative Law, Vol. 38, 1990.

\section{Legal Documents}

The 1945 Constitution of the Republic of Indonesia.

Law Number 3 of 2009 on the Second Amendment to the Law Number 14 of 1985 on the Supreme Court.

Law Number 8 of 2011 on the Amendment to the Law Number 24 of 2003 on the Constitutional Court.

Decision of the Constitutional Court Number 001-021-022/PUU-I/2003 on the Review of Law Number 20 of 2002 on Electricity.

Decision of the Constitutional Court Number 003/PUU-I/2003 on the Review of Law Number 24 of 2002 on Government Bonds.

Decision of the Constitutional Court Number 058-059-060-063/PUU-II/2004 and 008/PUU-III/2005 on the Review of Law Number 7 of 2004 on Water Resources.

Decision of the Constitutional Court Number 006/PUU-III/2005 on the Review of Law Number 32 of 2004 on Regional Government.

Decision of the Constitutional Court Number 012-016-019/PUU-IV/2006 on the Review of Law Number 30 of 2002 on the Commission for the Eradication of Corruption.

Decision of the Constitutional Court Number 11/PUU-V/2007 on the Review of Law Number 56, Prp of 1960 on the Size of Agricultural Land.

Decision of the Constitutional Court Number 12/PUU-V/2007 on the Review of Law Number 1 of 1974 on Marriage.

Decision of the Constitutional Court Number 54/PUU-VI/2008 on the Review of Law Number 39 of 2007 on Amendment to Law Number 11 of 1995 on Customs.

Decision of the Constitutional Court Number 27/PUU-VII/2009 on the Formal Review of Law Number 3 of 2009 on Amendment to Law Number 14 of 1985 on the Supreme Court.

Decision of the Constitutional Court Number 5/PUU/IX/2011 on the Review of Law Number 30 of 2002 on the Commission for Eradication of Corruption.

Decision of the Constitutional Court Number 48/PUU-IX/2011 on the Review of Law Number 24 of 2003 on the Constitutional Court and the Review of Law Number 35 of 2009 on Drugs. 
Decision of the Constitutional Court Number 49/PUU-IX/2011 on the Review of Law Number 8 of 2011 on the Amendment to Law Number 24 of 2003 on the Constitutional Court.

Decision of the Constitutional Court Number 8/PUU-X/2012 on the Review of Law Number 15 of 2011 on Electoral Commission.

Decision of the Constitutional Court Number 75/PUU-X/2012 on the Review of Law Number 32 of 2004 on Regional Government.

Decision of the Constitutional Court 11-14-21-126-136/PUU-XI/2013 on the Review of Law Number 20 of 2003 on the National Education System and Law Number 9 of 2009 on Educational Legal Entity.

Decision of the Constitutional Court Number 28/PUU-XI/2013 on the Review of Law Number 17 of 2012 on Cooperation.

Decision of the Constitutional Court Number 85/PUU-XI/2013 on the Review of Law Number 7 of 2004 on Water Resources.

Decision of the Constitutional Court Number 59/PUU-XIV/2016 on the Review of Law Number 11 of 2016 on Tax Amnesty.

Decision of the Constitutional Court Number 63/PUU-XIV/2016 on the Review of Law Number 11 of 2016 on Tax Amnesty.

Decision of the Indonesian Supreme Court Number: 54 P/HUM/2013.

Decision of the Indonesian Supreme Court Number: 62 P/HUM/2013.

Decision of the Indonesian Supreme Court Number: 64 P/HUM/2013.

Decision of the Indonesian Supreme Court Number: 11 P/HUM/2014.

Law Number 3318 on the National Security Act of South Korea.

German Criminal Code in the version of the Fifth Statute to Reform the Criminal Code, dated June 18, 1974.

Decision of the German Constitutional Court Number 7 Entscheidungen des Bundesverfassungsgerichts (BverfGE) 377, 1958.

Decision of the German Constitutional Court Number 30 Entscheidungen des Bundesverfassungsgerichts (BverfDE), Federal Constitutional Court, 1 (1975).

Decision of the United States Supreme Court, 447 U.S. 557, 1980.

Decision of the United States Supreme Court on Lujan v. Defenders of Wildlife, 504 U.S. 555, 560-561, 1992.

Decision of the Canadian Supreme Court, 1 S.C.R.103, 1986.

Decision of the South Korea Constitutional Court, Number 89-Honka-113, 1990. 